\title{
Physico-chemical quality control and dosage of total polyphenols, flavonoids of Morus alba Leaves (MORACEAE)
}

\author{
Camila B. Pereira*, Aline Marin**, Tiago D. T. Maki*k, Raquel M. M. \\ Necchi***, Melânia Palermo Manfron ${ }^{\star \star * *}$
}

\begin{abstract}
To establish parameters for quality control of Morus alba leaves were done tests of purity by determining the loss on drying, foreign matter, total ash, acid insoluble ash, swelling index, bitterness index, yield of crude extract, $\mathrm{pH}$ and organoleptic properties. The tests were done with samples collected on March, June, September and December according to Brazilian Pharmacopeia and World Health Organization. The percentage of loss on drying found are according to the established value of $14 \%$, the highest content was on September $12.89 \pm 0.1400 \%$. The indices of foreign matter found are agreement with the amount allowed by Brazilian Pharmacopeia, which establishes a maximum of $2 \%$ for most of the herbal drugs. The colletc on March showed the highest content of total ash and acid insoluble ash, respectively, $20.48 \pm 0.3517 \%$ and $5.68 \pm 0.1057 \%$. The swelling index showed higher values in samples collected on September $7.95 \pm 0.2186 \mathrm{~mL}$ and on December $7.1 \pm 0.8544 \mathrm{~mL}$. The bitterness index was higher in the first two collections, 1.037 units $/ g$ in both. The yield produced was 18 $\%$ on March, $29.61 \%$ on June, $26.47 \%$ on September and $24.35 \%$ on December. The $\mathrm{pH}$ of aqueous extract was neutral $(\mathrm{pH} 7.0)$ on March and slightly acid ( $\mathrm{pH} \mathrm{6.0)}$ in other months. The four collect showed small variations in relation the organoleptic properties. It was done dosage of total polyphenols and flavonoids with $70 \%$ ethanol extracts of $M$. alba leaves. The content found of polyphenols were $6.467 \pm 0,012 ; 5.503 \pm 0.007 ; 6.016 \pm 0.020 ; 6.943 \pm 0.046$ milligrams of gallic acid per gram of dried plant on March, June, September and December, respectively. The content of flavonoids found were $4.345 \pm 0.008 ; 3.782 \pm 0.016 ; 4.362 \pm 0.005 ; 4.893 \pm 0.013$ milligrams of rutin per gram of dried plant.
\end{abstract}

Descriptors: Morus alba; Moraceae; Quality Control; Leaves.

\section{Controle de qualidade físico-químico e dosagem de polifenóis totais e favonóides nas folhas de Morus alba (MORACEAE)}

RESUMO: Visando estabelecer parâmetros para o controle de qualidade das folhas de Morus alba foram realizados ensaios de pureza através das determinações de umidade, matéria estranha, cinzas totais, cinzas insolúveis em ácido, teor de mucilagem, índice de amargor, rendimento do extrato bruto, propriedades organolépticas e $\mathrm{pH}$. Os ensaios foram realizados com amostras coletadas em março, junho, setembro e dezembro, de acordo com a Farmacopéia Brasileira e a Organização Mundial de Saúde. A perda por dessecação apresentou teor de umidade de acordo com o valor estabelecido de 14 $\%$, o valor mais elevado foi em setembro $12.89 \pm 0,1400 \%$. Os índices de matéria estranha encontrados estão de acordo com a quantidade permitida pela Farmacopéia Brasileira, que estabelece um máximo de $2 \%$ para a maioria das drogas vegetais. A coleta de março apresentou o maior teor de

\footnotetext{
*Mestranda em Ciência e Tecnologia Farmacêuticas pela Universidade Federal de Santa Maria (UFSM), RS, Brasil.

**Aluno de graduação em Farmácia pela Universidade Federal de Santa Maria (UFSM), RS, Brasil.

*** Mestre em Ciência e Tecnologia Farmacêuticas pela Universidade Federal de Santa Maria (UFSM), RS, Brasil

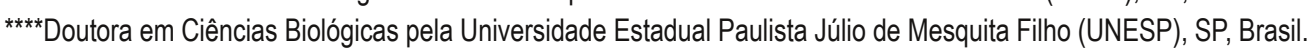


cinzas totais e cinzas insolúveis em ácido, respectivamente, $20,48 \pm 0,3517 \%$ e 5,68 $\pm 0,1057 \%$. 0 índice de intumescência mostrou valores mais elevados nas amostras coletadas em setembro $7.95 \pm$ $0,2186 \mathrm{~mL}$ e dezembro $7.1 \pm 0,8544 \mathrm{~mL}$. 0 índice de amargura foi mais elevado nas duas primeiras coletas 1,037 unidades/g em ambas. O rendimento produzido foi $18 \%$ em março, 29,61 \% em junho, $26,47 \%$ em setembro e $24,35 \%$ em dezembro. $\mathrm{O} \mathrm{pH}$ do extrato aquoso foi neutro $(\mathrm{pH} 7,0)$ em março e levemente ácido $(\mathrm{pH} \mathrm{6,0)}$ nos outros meses. As quatro coletas apresentaram pequenas variações em relação as propriedades organolépticas. Foi realizada dosagem de polifenóis e flavonóides com 0 extrato etanólico $70 \%$ das folhas de $M$. alba. $O$ valor de polifenóis encontrado em março, junho, setembro e dezembro foi $6.467 \pm 0,012 ; 5.503 \pm 0.007 ; 6.016 \pm 0.020 ; 6.943 \pm 0.046$ miligramas de ácido gálico por grama de planta seca, respectivamente. 0 valor de flavonóides encontrado foi $4.345 \pm$ $0.008 ; 3.782 \pm 0.016 ; 4.362 \pm 0.005 ; 4.893 \pm 0.013$ miligramas de rutina por grama de planta seca.

Descritores: Morus alba; Moraceae; Controle de qualidade; Folhas.

\section{Introduction}

The use of medicinal plants in therapy requires quality of herbal drugs, which begins on the correct identification of species, planting, harvesting, preparation of plant extracts and medicines. Therefore, it is necessary to obtain parameters of quality for pharmaceutical purposes, which are set out in Pharmacopeias and Officers Codes.

Family Moraceae occurs in tropical and subtropical regions and subdivided into approximately 60 genera, which comprise about 1400 species. ${ }^{1}$ The genus Morus is distinguished by its inflorescence spike amentacea type. Inflorescence is formed during months of July and August, with small flowers, often single-sex. They have corolla and a cup formed by four free sepals. ${ }^{2}$ Due to diversity of species of fruits, they are known as whitemulberry ( $M$. alba), blackberry ( $M$. nigra), cranberry-red ( $M$. rubra) and bramble-rose ( $M$. rosea). The main cultivated are white-blackberry and blackberry because they don't have thorns. They are adapted to different soil types, except those with trend water logging. ${ }^{3-6}$ The Moraceae family leaves are rich in protein, fiber, minerals and vitamin $C$, they also show a type of glycoprotein, called moran A, which is atributted an antidiabetic effect. ${ }^{7}$ The genus Morus has a variety of phenolic compounds including isoprenyl flavonoids, coumarins, chromones and xanthones. Many of these compounds exhibit biological properties such as antiinflammatory, diuretic and hypotensive effects. ${ }^{1}$ The leaves, bark and branch of $M$. alba (Fig. 1), are used in traditional medicine as antihyperglycemic, to treat fever, to protect the liver, to improve eyesight and to strengthen joints. ${ }^{8-9}$ Due to lack $M$. alba in monographs, this work aims to establish standards of quality and purity of plant drug by physico-chemical analysis and evaluation of total polyphenols and flavonoids in four collections during the year. The physico-chemical analysis carried out were: determination of loss on drying, foreign matter, yield of ethanol extrac, total ash, sulphated ash, swelling index, bitterness index, $\mathrm{pH}$ and organoleptic properties.

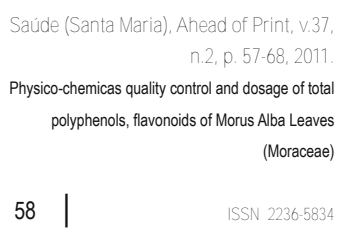




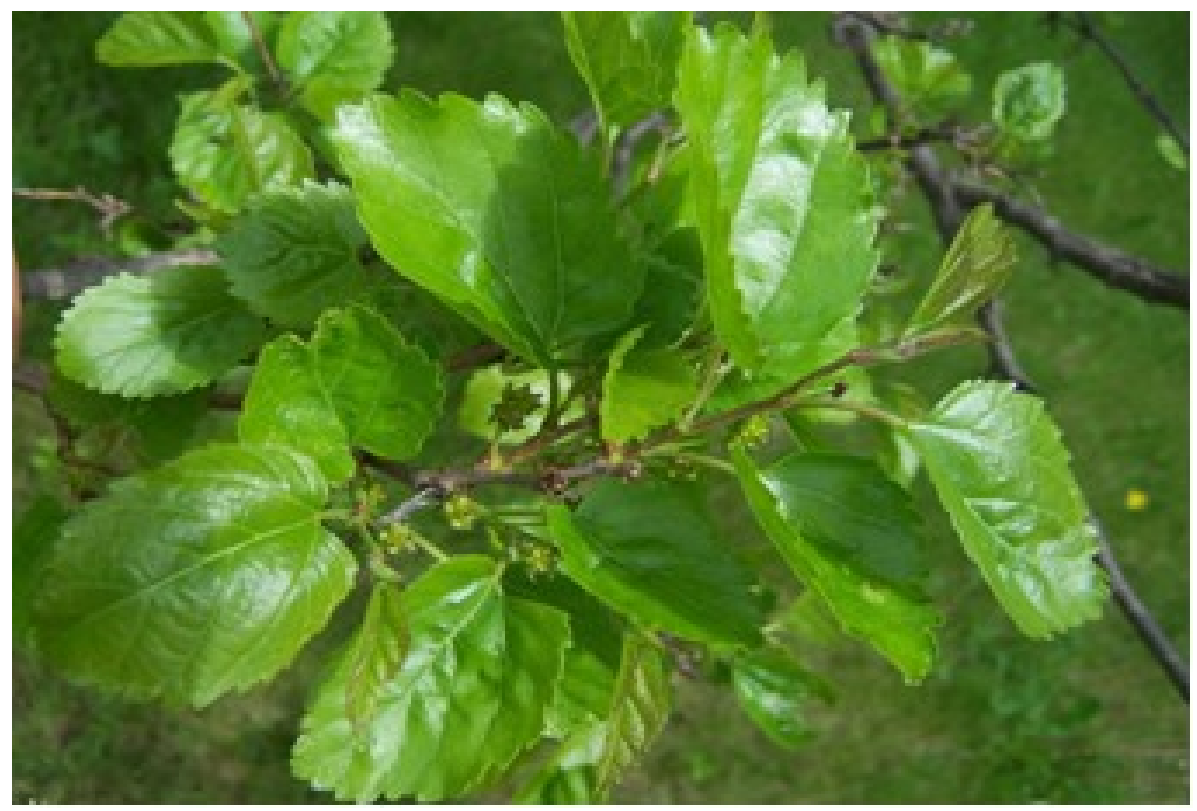

\section{Material and methods}

\section{Plant material}

The Morus alba leaves were collected in March, June, September and December 2010, in Santa Maria city, Rio Grande do Sul State, Brazil. A sample of plant material was identified by $\mathrm{Dr}^{\mathrm{a}}$ Jumaida Maria Rosito and voucher specimens were deposited in the Herbarium of Biology Department of the Federal University of Santa Maria (UFSM) as voucher specimen SMDB 13079. The plant material was dried at $40^{\circ} \mathrm{C}$ with air circulation and grounded in a knife mill.

\section{Preparation of ethanol extract}

The extracts were obtained by cold maceration of powdered plant drug $(80 \mathrm{~g})$ with drug solvent ratio $20 \%$ (w/v) in $70 \%$ hydroetanolic solvent during 30 days, after this, they were concentrated, lyophilizated and calculated yield.

\section{Physical-chemistry quality control}

\section{Loss on drying}

The water determination was performed according to Brazilian Pharmacopeia. ${ }^{10}$ It was weighed exactly $1 \mathrm{~g}$ of powdered plant drug and it underwent heating in an oven at $105{ }^{\circ} \mathrm{C}$ during 5 hours. The loss of drying weight was calculated considering the air-dried sample. The analysis was performed in triplicate. 


\section{Foreign matter}

Macro e microscopy examination was conveniently employed to determine the presence of foreign matter in powdered plant drug according to Brazilian Pharmacopeia. ${ }^{10}$ In the macroscopy examination, $25 \mathrm{~g}$ of plant drug was spread on a thin layer from which the foreign matter was selected by inspection through the magnifying less. The content of foreign matter was calculated considering the air-dried sample. The analysis was performed in triplicate.

\section{Total ash}

The analysis of total ash was conducted according to Brazilian Pharmacopeia.10 The powdered plant drug $(3 \mathrm{~g})$ was accurately weighed into a crucible that has been previously ignited, cooled and weighed. Then the sample was ignited by gradual heating to $450{ }^{\circ} \mathrm{C}$, cooled in a desiccator and weighed. For obtaining carbon-free ash, the residue was moistened whit $2 \mathrm{~mL}$ of water after cooling the crucible. The remaining material was dried on a water-bath and then placed on a hot-plate, being ignited again until constant weight. The residue was cooled in a desiccator for 30 minutes and weighed. Total ash content was calculated considering the dry material. The analysis was performed in triplicate.

\section{Acid insoluble ash}

The analysis of acid insoluble ash was conducted according to Brazilian Pharmacopeia. ${ }^{10}$ In the crucible containing the total ash, it was added $25 \mathrm{~mL}$ of hydrochloric acid $(70 \mathrm{~g} / \mathrm{L})$, covered with a watch-glass and boiled gently for 5 minutes. The watch-glass was rinsed with 5 $\mathrm{mL}$ of hot water and then this liquid was added to the crucible. The insoluble matter was collected on an ashless filter-paper and washed with hot water until the filtrate was neutral. Thereafter, the filter-paper containing the insoluble matter was transferred to the original crucible, which was dried on a hot-plate and ignited to constant weight. After cooling the residue in a desiccator, the crucible was weighted and the content of acid-insoluble ash calculated considering the dry material. The analysis was performed in triplicate.

\section{Swelling index}

The analysis of swelling index was conducted according to Brazilian Pharmacopeia. ${ }^{10}$ One gram of powdered plant drug was introduced into a $25 \mathrm{~mL}$ glass-stoppered measuring cylinder for the verification of the volume occupied by the sample. Next, $25 \mathrm{~mL}$ of water was added and the mixture was shaken thoroughly every 10 minutes for about 1 hour. After that, the mixture was stood for 3 hours at room temperature, and finally the volume in $\mathrm{ml}$ occupied by the plant material was remeasured. The test was performed in triplicate.

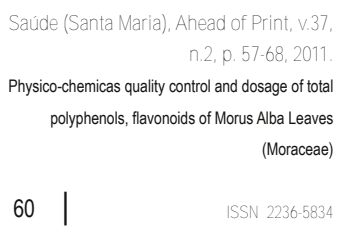

\section{Bitterness index}

The determination of the index of bitterness was performed according to Brazilian Pharmacopeia. ${ }^{10}$ The bitter properties of plant material were determined by comparing the 
threshold bitter concentration of the extract from the material with the concentration from a dilute solution of quinine hydrochloride. Drinking-water was the vehicle to the extraction of plant materials and for the mouth-wash after each tasting. It's was prepared a stock solution (St) of $M$. alba at $1 \%(\mathrm{w} / \mathrm{v})$. St was transferred to 10 tubes with volumes from 1 to $10 \mathrm{~mL}$. The standard solution of quinine hydrochloride $R$ was distributed in nine tubes from 0.042 to 0.058 $\mathrm{mg} / 10 \mathrm{~mL}$. The birtteness value was expressed in units equivalent to the bitterness of a solution containing $1 \mathrm{~g}$ of quinine hydrochloride in $2000 \mathrm{~mL}$.

Yield

The analysis of yield was conducted according to Costa. ${ }^{11}$ The yield was determined using the equation: Yield $(\%)=\mathrm{Mf} / \mathrm{Mi} X 100$, where Mi is the initial mass of sample $(\mathrm{g})$ and Mf is the final mass of the dry extract $(\mathrm{g})$. Crude extracts were obtained by cold maceration of powdered plant drug $(80 \mathrm{~g})$ with drug solvent ratio $20 \%$ (w/v) in $70 \%$ hydroetanolic solvent during 30 days and the yield determined. Botanical studies of yield must be performed as an indicative of correct amount of material to be collected for production of extracts and fractions used in pharmacological tests.

\section{Organoleptic properties and $\mathrm{pH}$}

The organoleptic features analyzed were odour, flavor and color. The odour was checked by pressing of a small portion of leaves on the palm of the hand, inhaling slowly and repeatedly. The color of the leaves was analyzed with fresh plant under diffuse daylight. The flavor was tasted through the instillation of few drops on tongue of an aqueous solution $1 \%$ $(\mathrm{w} / \mathrm{v})$ of the powdered plant drug heated on an eletric-plate and brought to be boiling for 5 minutes. ${ }^{12} \mathrm{pH}$ was verified by potentiometry with the above solution, according to Brazilian Pharmacopeia. ${ }^{13}$

\section{Dosage of total polyphenols}

The dosage of polyphenols was performed through the Folin-Ciocalteau, with some modifications. ${ }^{14-15}$ Based on the solution of $0.04 \%$ of the ethanol extract of $M$. alba, solutions was prepared in volumetric flasks at concentrations of $5,10,20,30 \mu \mathrm{g} / \mathrm{mL}$. To this end, we used the required amount of solution of $0.04 \%$ with addition of $1 \mathrm{~mL}$ of Folin-Ciocalteau for 5 minutes, $2 \mathrm{~mL}$ of sodium carbonate $\left(\mathrm{Na}_{2} \mathrm{CO}_{3}\right) 20 \%$ for 10 minutes. The solutions were homogenized, capped and protected from light and kept at room temperature. The absorbance was measured at $730 \mathrm{~nm}$ using water as a blank. The test was performed in triplicate. The standard curve was obtained using standard solutions of gallic acid at the same concentration of the sample. The content of total polyphenols was expressed as milligram of gallic acid equivalent per gram of dried plant. 


\section{Dosage of flavonoids}

The dosage of flavonoids was performed according to a modified methodology from Rio ${ }^{16}$. Based on the solution of $0.04 \%$ of the ethanol extract of $M$. alba, solutions was prepared in volumetric flasks at concentrations of $10,20,50,100,150 \mu \mathrm{g} / \mathrm{mL}$. To this end, we used the required amount of solution of $0.04 \%$ with addition of $75 \quad$ I of $5 \%$ methanol $(\mathrm{MeOH})$ solution of $\mathrm{AlCl}_{3}, 3.9 \mathrm{~mL}$ of methanol $70 \%$ for 30 minutes. The solutions were homogenized, capped and protected from light and kept at room temperature. The absorbance was measured at $425 \mathrm{~nm}$ using $\mathrm{MeOH} 70 \%$ as a blank. The test was performed in triplicate. The standard curve was obtained using standard solutions of rutin at the same concentration of the sample. The flavonoids content was expressed as milligram of rutin equivalent per gram of dried plant.

\section{Statistical analysis}

Results were expressed as mean \pm standard error of mean (SEM). Statistical analysis was performed using One-way ANOVA followed by Tukey test using Graph Prism 5.0 software (Graph Pad Software, San Diego, CA, USA) and the results were considered significant when $p<0.05$.

\section{Results and discussion}

\section{Physico-Chemical Quality Control}

The loss on drying of $M$. alba leaves showed a moisture content according to the established value of $14 \%$, which is the maximum limit recommended of moisture for plant drugs. ${ }^{12 ; 13 ; 17}$ According to Simões ${ }^{18}$ the water founded in the plant drug is directly related to its storage and microbial contamination or enzymatic degradation by action of the chemical constituents. The excess of water in the raw material enables the development of fungi and bacteria. ${ }^{19}$ Therefore, preliminary operations employed in the leaves were effective in standardizing of moisture content to established values. Through statistical analysis were checked significant differences in the loss on drying in the four collections (table 1).

\begin{tabular}{ccc}
\multicolumn{2}{c}{ Table 1- Loss on drying, mean \pm standard error of mean (SEM) of Morus alba leav } \\
\hline Month & Mean (\%) & SEM \\
\hline March & 9.73 & \pm 0.1253 \\
June & 11.15 & \pm 0.2118 \\
September & 12.89 & \pm 0.1400 \\
December & 8.56 & \pm 0.0808 \\
\hline
\end{tabular}

Saúde (Santa Maria), Ahead of Print, v.37, n.2, p. 57-68, 2011. Physico-chemicas quality control and dosage of total polyphenols, flavonoids of Morus Alba Leaves ISSN 2236-5834

(Moraceae) ount allowed by Brazilian Pharmacopeia, ${ }^{10}$ which establishes a maximum of $2 \%$ for most of the herbal drugs (table 2). Collections made during September and December didn't show 
foreign matter. There weren't significant differences in the indices of foreign matter in the four collections. The amount of foreign matter may be related to the fact of leaves have been preselected and milled. ${ }^{20}$ Analysis for determination of foreign matter has the purpose to identify portions or products not specified in the definition and description of the drug, besides impurities from mineral or organic nature, don't related to the drug. ${ }^{13}$

Table 2 - Foreign matter, mean \pm standard error of mean (SEM) of Morus alba leaves

\begin{tabular}{ccc}
\hline Month & Mean (\%) & SEM \\
\hline March & 0.0200 & \pm 0.0121 \\
June & 0.0126 & \pm 0.0063 \\
\hline
\end{tabular}

The determination of contenting total ash is important for quality control, since its aim is to check the presence of non-volatile inorganic impurities that may contaminate the plant drug. 10;21 The colletc that had the highest content of total ash was done on March (table 3). This can be explained by the higher amount of inorganic salts present in the first collection. ${ }^{17}$

In the analysis of acid insoluble ash was possible to observe a large discrepancy in values. In the gathering done on March and December, the content found was $5.68 \%$ and $3.50 \%$, respectively. Through statistical analysis were checked significant differences in the content of total ash and acid insoluble ash in the four collections. Determination of ash insoluble in acid chloridric is intended to detect constituents of silica and siliceous constituients, wich above of the established for the plant drug indicates contamination by excess soil or sand. ${ }^{13}$ There is not maximum value for total ash and acid insoluble ash officially established for the species in study.

Table 3 - Determination of total ash, acid insoluble ash, mean \pm standard error of mean (SEM) of Morus alba leaves.

\begin{tabular}{ccc}
\hline Month & Total ash (\%) & Acid insoluble ash (\%) \\
\hline March & $20.48 \pm 0.3517$ & $5.68 \pm 0.1057$ \\
June & $9.57 \pm 0.4908$ & $0.75 \pm 0.0333$ \\
September & $11.88 \pm 0.2408$ & $1.67 \pm 0.0738$ \\
December & $17.86 \pm 0.4020$ & $3.508 \pm 0.0601$ \\
\hline
\end{tabular}

Analyzing the swelling index, $M$. alba leaves showed the highest values in samples collected on September and December (Table 4). The significant differences were checked only in results obtained on September versus March and September versus June. Banderó 22 found a quantity of swelling index of $2.03 \mathrm{~mL}$ to Glechon spathulata. This test serves to measure the volume $(\mathrm{mL})$ occupied by plant matter plus mucilage or other material attached. ${ }^{12,13,17}$ 
Table $4-$ Swelling index, mean \pm standard error of mean (SEM) of Morus alba leaves.

\begin{tabular}{ccc}
\hline Month & Mean $(\mathrm{mL})$ & SEM \\
\hline March & 5.83 & \pm 0.1202 \\
June & 5.73 & \pm 0.0882 \\
September & 7.95 & \pm 0.2186 \\
December & 7.1 & \pm 0.8544 \\
\hline
\end{tabular}

Pharmacopeias and specialist books on herbal drugs include certain types of sensation like flavour. Analysis of the bitterness index is determined by comparing the threshold concentration of bitterness of an extract and the dilute solution of quinine chloride. Thus, there are astringent, oily, mucilaginous, bitter and pungent tastes. The bitterness index was higher in the first two collections (table 5), it shows that the drug contains bitter substances, especially considering the dilution used in the test. To Wasicky et al., ${ }^{23}$ bitterness index has solid bases theoretical and experimental, which competes with the best biological methods. However, Mello et al., ${ }^{24}$ affirmed that this test may introduce errors due to individual variability, since it doesn't statistically reproducing real information. Thus, to perform this test it is necessary a previous training of experimenter, which combined with statistical analysis, allow that the biological variability be minimized, becoming a reliable method.

There were differences in about $11 \%$ in yield's assessment of $70 \%$ ethanol extracts. The highest yields were on June and September. The $\mathrm{pH}$ of the aqueous extract was neutral $(\mathrm{pH}$ 7.0) on March and slightly acid ( $\mathrm{pH} \mathrm{6.0)} \mathrm{in} \mathrm{other} \mathrm{months,} \mathrm{this} \mathrm{suggests} \mathrm{presence} \mathrm{of} \mathrm{neutral} \mathrm{and}$ acid substances, respectively, in $M$. alba leaves.

Table 5 - Bitterness index, yield, $\mathrm{pH}$ of Morus alba leaves.

\begin{tabular}{cccc}
\hline Month & Bitterness index (units/g) & Yield (\%) & pH \\
\hline March & 1.037 & 18.0 & 7 \\
June & 1.037 & 29.61 & 6 \\
September & 0.84 & 26.47 & 6 \\
December & 0.84 & 24.35 & 6 \\
\hline
\end{tabular}

In relation the organoleptic properties, the four collect showed small variations, they were odorless and the aquous extract showed a slight bitter flavor. The fresh leaves showed a light green color in the collection of March, mid-green on June and September and dark green on December. Total polyphenols content found in ethanol extracts of $M$. alba on March, June, September and December were $6.467 \pm 0,012 ; 5.503 \pm 0.007 ; 6.016 \pm 0.020 ; 6.943 \pm 0.046$ milligrams of gallic acid per gram of dried plant (figure 2). The regression curve obtained was $Y$ $=0.2879 x-0.0685(R=0.9912)$. The highest content of polyphenols was found in collection on December $(6.943 \pm 0.046 \mathrm{mg} / \mathrm{g})$. The content of flavonoids found was $4.345 \pm 0.008 ; 3.782$

Saúde (Santa Maria), Ahead of Print, v.37, n.2, p. 57-68, 2011. Physico-chemicas quality control and dosage of total polyphenols, flavonoids of Morus Alba Leaves (Moraceae) regression curve obtained was $Y=0.1821 x-0.1545(R=0.9935)$. 
Figure 2 - Contents of polyphenols and flavonoids in ethanol extracts produced in four seasons.

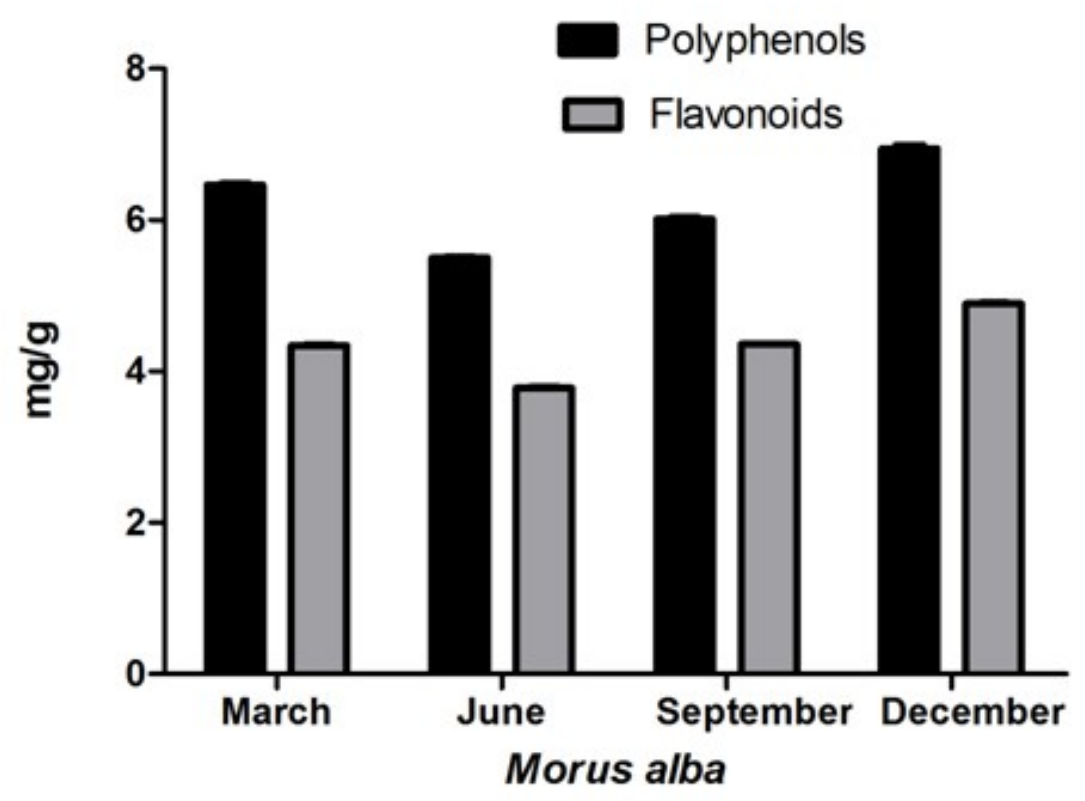

Plants can accumulate phenolic compounds in their metabolism under various stress conditions. ${ }^{25,26}$ Second Paliyath et al., ${ }^{27}$, most plants suffer physiological and biochemical damage by exposure to different temperatures. Sývacý et.al., ${ }^{28}$ found significant differences in polyphenol content of $M$. nigra and $M$. alba stem in the four seasons.

Through statistical analysis used in this study, was checked significant differences in the polyphenol and flavonoids content in four collections, only on March versus September there were not significant differences in flavonoids content. This fact can be explained by changes in climate, collection time, soil formation, plant age, temperature and total rainfall. The information obtained in this study has been relevant to characterization and physico chemical quality control of $M$. alba leaves.

\section{Conclusion}

Due to widespread use of $M$. alba leaves in traditional medicine, it is necessary to obtain quality standard for the use of this plant. The methods employed were adequate to assess the quality control of vegetable drugs in study, since it hasn't description in Pharmacopoeias. The dosages of polyphenols and flavonoids in the four colletions showed higher content in summer.

\section{References}

1. Nomura T, Hano T. Isoprenoid-substituted phenolic compounds of moraceus plants. Nat. Prod. Rep. 1994; 11: 205-18.

2. Corradello, EFA. Bicho-da-seda e amoreira: da folha ao fio, a trama de um segredo milenar. São Paulo: Ícone. 1987; p. 101.

Saúde (Santa Maria), Ahead of Print, v.37, n.2, p. 57-68, 2011.

3. Donadio LC, Nachtigal, JC, CK, Sacramento. Frutas exóticas. Jaboticabal:FUNEP. 1998; p. 279. 
5. Donadio LC. Dicionário das frutas. Jaboticabal. 2007; p. 300.

6. Gomes P. Fruticultura brasileira 13ª ed. São Paulo: Nobel. 2007; p. 446.

7. Andallu B, Vardacharyulun CH. Effect of mulberry leaves on diabetes. Int. J. Diab. Dev. Countries. 2001; 21: $147-51$.

8. Zhishen J, Mengcheng T, Jianming W. The determination of flavonoid contents in mulberry and their scavenging effects in superoxide radicals. Food Chemistry. 1999; 64: 555-59.

9. Kim SU, Kim LHS, Kim I, MY, Kim, KS Ahn. Determination of 1deoxynojirimycin in Morus alba L. leaves through derivatization with 9-fluorenylmethyl chloroformate followed by reversed-phase high performance liquid chromatography. Journal of Chromatography. 2003; 1002:93-9.

10. Farmacopéia Brasileira. 4. ed. São Paulo: Atheneu. 2000

11. Costa AF. Farmacognosia. Lisboa: Fundação Calouste Gulbenkian. 4 ed.; 1994; v.2, p. 1117.

12. World Health Organization. Quality Control Methods for Medicinal Plant Materials. Geneva, 1998, p.122.

13. Farmacopéia Brasileira. 4. ed. São Paulo: Atheneu. 1988.

14. Simonovska B, Vovk I, Andrensek S, Valentova K, Ulrichova J. Investigation of phenolic acids in yacon (Smallanthus sonchifolius) leaves and tubers. Journal of Chromatography. 2003; 1016(1), 89-98.

15. Kumazawa S, Hamasaka T, Nakayama T. Antioxidant activity of propolis of various geographic origins. Food Chem. 2004; 84:329-39.

16. Rio RGW. Métodos de controle químico de amostras de própolis. Dissertação de mestrado. Universidade de São Paulo, São Paulo. 1996

17. Hänsel R, Sticher O, Steinegge RE. Pharmakognosie - Phytopharmazie.Berlin: Springer. 1999

18. Simões CMO, Mentz LA, Schenkel EP, Irgang BE, Stehmann JR. Plantas da medicina popular no Rio Grande do Sul. 5. ed. Porto Alegre: Ed. Universidade/UFRGS. 1998, p. 173.

19. Farias, MR. Avaliação da qualidade de matérias-primas vegetais In: Simões, C.M.O. et al (Org.). "Farmacognosia: da planta ao medicamento". 5. ed. Porto Alegre/Florianópolis: Ed. Universidade - UFRGS/ Ed. da UFSC. 2003

20. Frasson, APZ, Bittencourt CF, Heinzmann BM. Caracterização físico química e biológica do caule de Caesalpinia ferrea Mart. Rev. Bras. Farmacog. 2003; 13: 35-9.

21. Sonaglio D, Ortega $G G$, Petrovick $P R$, Bassani VL. Desenvolvimento tecnológico e produção e fitoterápicos. In: Simões C.M.O, E.P. Schenkel, M.J.C.P. Gosmann, L.A. Mentz., P.R. Petrovick. Farmacognosia: da planta ao medicamento. 5.ed. Porto Alegre/Florianópolis: Editora da UFRGS/ Editora da UFSC. 2003

22. Banderó VC. Physico-chemical characterization for qualiy control of Glechon spathulata. Dissertação de Mestrado, Progama de Pós-graduação em Ciências Farmacêuticas, Universidade Federal de Santa Maria. 2009

23. Wasicky R, Barbieri E, Weber H. Contribuição para o método de dosagem de princípios ativos em drogas e preparações pelo amargor. Anais da Faculdade de Farmácia e Odontologia da Universidade de São Paulo. 1943; 3: 113-19.

24. Mello JCP, Petrovick PR. Quality control of Baccahris trimera (Less) DC (Asteraceae) hydroalcoholic extracts. Acta Farm Bonaerense. 2000; 19: 211-15.

Saúde (Santa Maria), Ahead of Print, v.37, n.2, p. 57-68, 2011. Physico-chemicas quality control and dosage of total polyphenols, flavonoids of Morus Alba Leaves

25. Pasqualini V., Robles C., Garzino S., Greff S., Bousquet MA, Bonin G.. Phenolic compounds content in Pinus halepensis Mill needles: a bioindicator of air pollution. Chemosphere. 2003; 52:239-48.

26. Christie PJ, Alfenito MR, Walbot V. Impact of low-temperature stress on general phenilpropanoid and anthocyanin pathways: enhancement of transcript abundance and anthocyanin pigmentation in maize 
seedlings. Planta. 1994; 194: 541-49.

27. Paliyath G., Pinhero RG, Rao MV, Murr DP. Fletcher RA. Changes in activities of antioxidant enzymes and their relationship to the genetic and paclobutrazol-induced chilling tolerance in maize seddlings. Plant Physiol. 1997; 114:695-704.

28. Sývacý A., Sökmen M. Seasonal changes in antioxidant activity, total phenolic and anthocyanin constituent of the stems of two Morus species (Morus alba L. and Morus nigra L.) Plant Growth Regulation. 2004; 44: 3251-256.

\section{Camila Bugnotto Pereira}

Endereço para correspondência - Programa de Pós-Graduação em Ciências Farmacêuticas, Universidade

Federal de Santa Maria, Prédio 26, Santa Maria, RS, Brasil.

CEP: $97105-900$

E-mail: camilabugno@hotmail.com

Currículo lattes: http://lattes.cnpq.br/5954851418582018

Recebido em 01 de junho de 2011.

Aprovado em 30 de agosto de 2011. 
Saúde (Santa Maria), Ahead of Print, v.37,

n.2, p. 57-68, 2011.

Physico-chemicas quality control and dosage of total

polyphenols, flavonoids of Morus Alba Leaves

(Moraceae)

$68 \mid$ ISSN 2236-5834 